\title{
Balto-Slavic Language
}

National Cancer Institute

\section{Source}

National Cancer Institute. Balto-Slavic Language. NCI Thesaurus. Code C161855.

A branch of the Indo-European family of languages. It traditionally comprises the Baltic and Slavic languages. 